\title{
Mineralogical characterization and beneficiation study of kaolin from Equador (RN) and Junco do Seridó (PB) to increase the brightness index
}

\section{(Caracterização mineralógica e estudo do beneficiamento do caulim de Equador (RN) e Junco do Seridó (PB) para elevação do índice de alvura)}

\author{
V.M.J.S. Campos ${ }^{1^{*}}$, L.C.Bertolino ${ }^{1}$, O.C. Alves ${ }^{2}$ \\ ${ }^{1}$ Sector for Technological Characterization, Division of Mineral Analysis, Center for Mineral Technology, \\ Av. Pedro Calmon 900, Rio de Janeiro, RJ 21941-908 \\ ${ }^{2}$ Department of Physicochemistry, Chemistry Institute, Fluminense Federal University, \\ R. Outeiro de S. J. Batista s/n, Niterói, RJ 24020-150 \\ *vcampos@cetem.gov.br,lcbertolino@cetem.gov.br, odivaldocambraia@id.uff.br
}

\begin{abstract}
Kaolin is a rock composed mainly of kaolinite. It is used in many industrial segments, such as paper and ceramics. However, for these uses it is necessary to submit the ore to appropriate beneficiation, which generally involves magnetic separation and chemical bleaching, aiming to remove iron oxide and hydroxide, raising brightness index. This work reports the mineralogical characterization and analysis of the beneficiation of three samples of kaolin, two from Equador (Rio Grande do Norte - RN) and the third from Junco do Seridó (Paraíba $\mathrm{PB})$. The samples were submitted to granulometric classification in sieve of $44 \mu \mathrm{m}$, magnetic separation in a magnetic induction of 14000 gauss, and chemical bleaching with sodium dithionite during $240 \mathrm{~min}$. The processes were divided into two beneficiation routes. X-ray diffraction, chemical analysis by X-ray fluorescence and scanning electron microscopy were used for mineralogical characterization of the ore and measurement of the brightness index, while electron paramagnetic resonance was applied to study the variation of iron oxides and hydroxides during beneficiation. The results indicate that just $30 \mathrm{~min}$ of chemical bleaching without magnetic separation was sufficient to increase the brightness index from 78.2 to $90.2 \%$ and from 91.3 to $95.7 \%$ in the two samples from Equador (RN) and from 86.9 to $90.4 \%$ in the sample from Junco do Seridó (PB). The magnetic separation, although causing a small increase in the brightness index, was inefficient for removal of iron oxides and hydroxides. The results indicated no need for using magnetic separation in plants for beneficiation of kaolin from these two locations, providing the reduction of production costs allowing better exploitation of the ore.
\end{abstract}

Keywords: magnetic separation, chemical bleaching, electron paramagnetic resonance, iron oxides and hydroxides.

\section{Resumo}

Caulim é a rocha constituída principalmente por caulinita. É usado em diversos segmentos industriais, como os de papel e cerâmica. Contudo, para tais fins, é necessário que o minério seja submetido a processos de beneficiamento adequados, que geralmente envolvem separação magnética e alvejamento químico visando a remoção de óxidos elou hidróxidos de ferro, resultando em elevação no índice de alvura do minério. O estudo teve como objetivo a caracterização mineralógica e a análise do beneficiamento de duas amostras de caulim de Equador (RN) e uma de Junco do Seridó (PB). As amostras foram submetidas a classificação granulométrica em 44 m, separação magnética em indução de 14000 gauss e alvejamento químico com ditionito de sódio durante 240 min, onde os processos foram distribuídos em duas rotas de beneficiamento. Foram realizadas as técnicas de difratometria de raios $X$, análise química por fluorescência de raios $X$ e microscopia eletrônica de varredura visando a caracterização mineralógica do minério e a determinação do índice de alvura e as análises de ressonância paramagnética eletrônica para o estudo da variação dos óxidos elou hidróxidos de ferro durante o beneficiamento. Os resultados indicaram que apenas 30 min de alvejamento químico sem separação magnética foram suficientes para as maiores remoções de óxidos elou hidróxidos de ferro, resultando nas maiores elevações de índice de alvura de 78,2 para 90,2\% e 91,3 para 95,7\% nas amostras de Equador (RN) e de 86,9 para 90,4\% na de Junco do Seridó(PB). Já a etapa de separação magnética, embora promova pequeno aumento de índice de alvura, foi pouco eficiente na remoção de óxidos elou hidróxidos de ferro. Os resultados indicaram a não necessidade da etapa de separação magnética em plantas de beneficiamento do caulim destas duas localidades, proporcionando a redução de custos de produção possibilitando uma melhor explotação do minério.

Palavras-chave: separação magnética, alvejamento químico, ressonância paramagnética eletrônica, óxidos elou hidróxidos de ferro.

\section{INTRODUCTION}

Kaolin is a rock composed principally of kaolinite [1]. It is white and it has fine grain, and is classified as primary when derived from in situ alteration of feldspar and as secondary when of sedimentary origin [2]. The deposits of kaolin in Equador (RN) and Junco do Seridó (PB) are included in the Pegmatitic Province of BorboremaSeridó [3] and are the result of alteration of feldspars into pegmatites associated with the Equador Formation [4]. The 
Table I - Mineralogical, chemical and physical characteristics of kaolin for use in papermaking, as filler and coating, and in ceramic industries [2].

[Tabela I - Características mineralógica, química e físicas para uso do caulim na indústria de papel, como revestimento e carga, e na indústria da cerâmica [2].]

\begin{tabular}{llll}
\hline Characteristic & Paper (coating) & Paper (filler) & Ceramics \\
\hline Mineralogical composition (\%) & & & \\
Kaolinite & $93-99$ & $90-95$ & - \\
Mica & $7-10$ & $5-10$ & - \\
Others & Trace & Trace & - \\
Chemical composition (\%) & & & \\
$\mathrm{SiO}_{2}$ & $45-47$ & $46-48$ & $48-49$ \\
$\mathrm{Al}_{2} \mathrm{O}_{3}$ & $37-38$ & $37-38$ & $36.1-37$ \\
$\mathrm{Fe}_{2} \mathrm{O}_{3}$ & $0.5-1.0$ & $0.5-1.0$ & $0.6-1.0$ \\
$\mathrm{TiO}_{2}$ & $0.5-1.3$ & $0.04-1.5$ & $0.02-0.1$ \\
Loss on ignition & $13.9-14.3$ & $12.3-13.7$ & $11.2-12.5$ \\
Particle size $(\%)$ & & & \\
Less than $2 \mu \mathrm{m}$ & $89-92$ & $60-80$ & $40-70$ \\
Less than $10 \mu \mathrm{m}$ & 100 & $85-97$ & $80-96$ \\
Less than $53 \mu \mathrm{m}$ & - & - & 100 \\
Physical properties & & & \\
Modulus of rupture after $110{ }^{\circ} \mathrm{C}\left(\mathrm{kgf} / \mathrm{cm}^{2}\right)$ & - & $82-85$ & $70-31$ \\
Brightness index $(\%$ ISO) & $90-92$ & - & - \\
Viscosity $(\mathrm{cps})$ & 74 & & \\
\hline
\end{tabular}

kaolin of the Borborema-Seridó Province is composed of kaolinite, muscovite, quartz and feldspar. Through proper beneficiation it is possible improve the properties of the material [5].

In Brazil, most kaolin is used in papermaking, where it is used as filler or coating, and in ceramic industries, provided it complies with determined quality levels [6]. In ceramic industries, kaolin can be used in the production of sanitary fixtures, tableware, refractory bricks, coated pieces and electric porcelain, where it can compose between 25 and $100 \%$ of the material. Nevertheless, for any application the ore needs to comply with determined standards (Table I). For this, the ore must be submitted to the suitable beneficiation. Wet beneficiation of kaolin involves granulometric classification in sieves with $44 \mu \mathrm{m}$, to remove the bulky particles, followed by magnetic separation in a strong magnetic field to remove iron oxides and hydroxides, and lastly, chemical bleaching to reduce iron (III) ions to iron (II) ions and consequent removal by filtration. The last two processes aim to raise the ore's brightness index [7].

However, the deposits of kaolin in Junco do Seridó, in Paraíba, and Equador, in Rio Grande do Norte, are still extracted in rudimentary way and there are few modern beneficiation plants. This situation and the rising costs of kaolin beneficiation in Brazil [8] indicate the need for further studies about the characteristics of kaolin and analysis of beneficiation to find more suitable treatment methods.
This work reports the mineralogical characterization and evaluation of the magnetic separation and chemical bleaching for removal of iron (III) ions from three samples of kaolin, two from Equador (RN) and one from Junco do Seridó (PB), aiming to determine the more suitable beneficiation process to remove iron oxides and hydroxides, resulting in a higher brightness index and consequently expanding its industrial applications.

\section{MATERIALS AND METHODS}

Three run of mine (ROM) samples of kaolin were collected from the same deposit, two in Equador (RN) and the other in Junco do Seridó (PB). The three samples weighed approximately $17 \mathrm{~kg}$. The samples were named GB2, GB1 and JS, respectively, and the metric coordinates of the collection sites were 754364E 9231863N, 754353E $9231943 \mathrm{~N}$ and $750498 \mathrm{E} 9225368 \mathrm{~N}$, respectively, where the UTM Zone is $24 \mathrm{M}$ and the Datum SIRGAS 2000 (Fig. 1).

The ROM samples were dried, homogenized, quartered and submitted to wet granulometric classification in vibratory sieves with $44 \mu \mathrm{m}$ aperture before being processed in two routes. The first consisted of magnetic separation and chemical bleaching and the second only the chemical bleaching (Fig. 2). The fractions obtained from magnetic separation were called non-mag. The magnetic separation was carried out in a Boxmag-Rapid separator in wet 


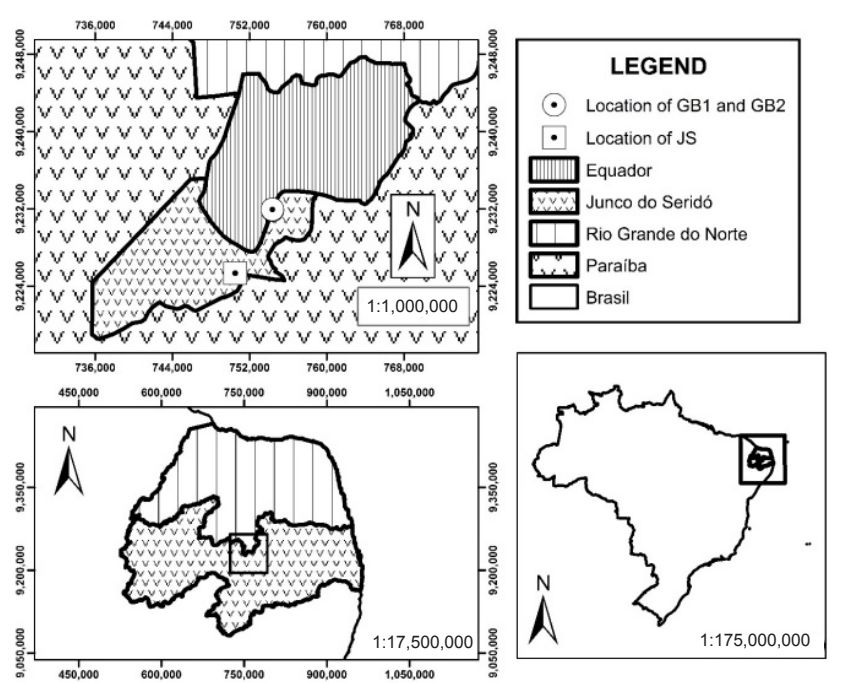

Figure 1: Location of collection of the samples GB2, GB1 and JS. Datum: SIRGAS 2000.

[Figura 1: Localização de coleta das amostras GB2, GB1 e JS. Datum: SIRGAS 2000.]

conditions and in a magnetic induction of approximately 14000 gauss. The chemical bleaching was done on a slurry containing $20 \%$ of kaolin and $80 \%$ distilled water, kept under stirring between 100 and $200 \mathrm{rpm}$. Sodium dithionite $\left(\mathrm{Na}_{2} \mathrm{~S}_{2} \mathrm{O}_{4}\right)$ was used as reducing agent in proportion of $4 \mathrm{~kg} / \mathrm{t}$ and sodium hexametaphosphate $\left(\mathrm{Na}_{16} \mathrm{P}_{14} \mathrm{O}_{43}\right)$ as dispersing agent in proportion of $3 \mathrm{~kg} / \mathrm{t}$. The $\mathrm{pH}$ of the suspension was maintained between 3 and 4 with addition of sulfuric acid and the process was carried out for $240 \mathrm{~min}$, where fractions were collected at intervals of $30 \mathrm{~min}$.

The fractions were analyzed by X-ray diffraction (XRD), $\mathrm{X}$-ray fluorescence (chemical analysis), scanning electron microscopy (SEM), electron paramagnetic resonance and the measurement of the brightness index. The analysis for mineral identification of the fractions was performed with a Bruker D4 Endeavor X-ray diffractometer with $\mathrm{CoK} \alpha$ radiation $(\lambda=0.179021 \mathrm{~nm})$ and with generator operating at $40 \mathrm{kV}$ and $40 \mathrm{~mA}$. The goniometer velocity was $0.02^{\circ}$

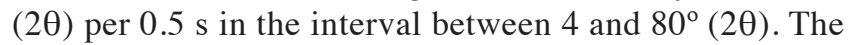
Hinckler indexes were obtained by the ratio where the numerator is the sum of the heights of the peaks (110) and (111), measured on a line between the peaks (020) and (110) until the background, and the denominator is the total height of the peak (110) [9]. The chemical analysis was carried out with a PANalytical Axios mAX spectrometer and the fractions were prepared in a VANEOX automatic press in molding conditions of $20 \mathrm{~mm}$ of diameter, with pressure of 20 ton and time of $30 \mathrm{~s}$, using boric acid $\left(\mathrm{H}_{3} \mathrm{BO}_{3}\right)$ as caking in proportions of 1:0.1. The scanning electron microscope images were obtained by a Bruker FEI Quanta 400 microscope and chemical microanalysis was performed with a Bruker Quantax 800 spectrometer and Bruker XFlash 5010 detector (spectral resolution of $129 \mathrm{eV}$ for $\mathrm{MnK} \alpha$ ), with previous spectral calibration. The microscope was operated in high vacuum mode and the samples were metalized with

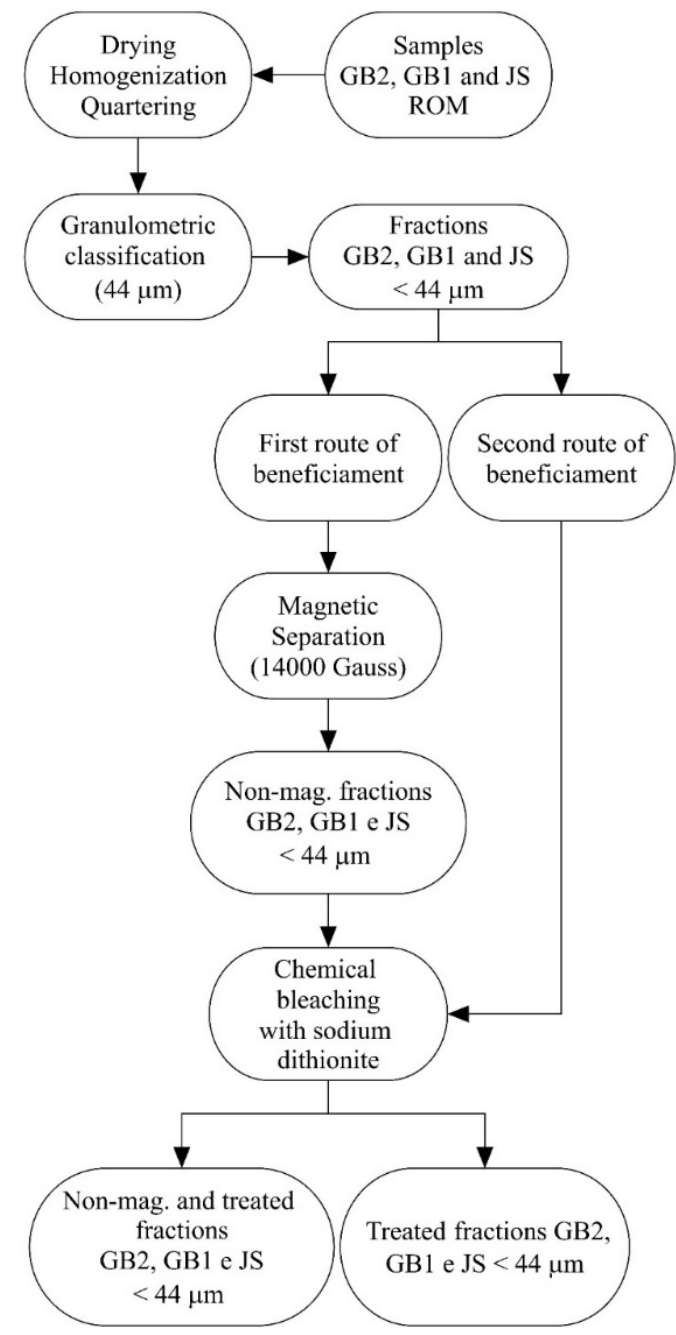

Figure 2: Flowchart of the two beneficiation routes for samples GB2, GB1 and JS.

[Figura 2: Fluxograma das duas rotas de beneficiamento realizadas nas amostras GB2, GB1 e JS.]

gold. The brightness index was determined with a Carl-Zeiss Elrepho 96160 photometer with a standard of $83.9 \%$ (ISO). The electron paramagnetic resonance spectra were obtained with a Bruker ESP300E spectrometer with X-band of 9.75 $\mathrm{GHz}$. The quantitative analysis was done with the absolute area percentage of the sigmoid between 200 and $400 \mathrm{mT}$ regarding the area between 100 and $500 \mathrm{mT}$ of the respective spectrum [10].

\section{RESULTS AND DISCUSSION}

The XRD patterns of the ROM GB2, GB1 and JS samples and respective fraction $<44 \mu \mathrm{m}$ (Fig. 3) indicate the presence of kaolinite, identified by the presence of the basal peaks $7.23 \AA$ (001) and $3.86 \AA(002)$, and by the triplets $4.48,4.35$ and $2.56 \AA$, and $2.53,2.49$ and $2.33 \AA$. Also identified, as impurities, were muscovite at 9.95 and $4.98 \AA$, quartz at $3.3 \AA$, and feldspar at $3.25 \AA$. The peaks referring to muscovite, quartz and feldspar decreased and the peaks of kaolinite increased in the XRD patterns of the fractions 


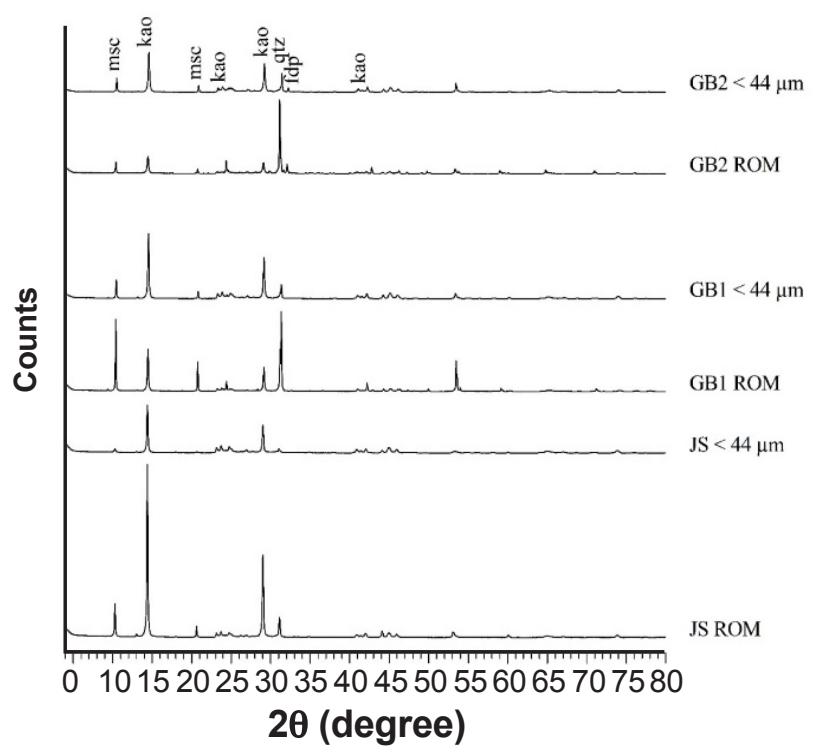

Figure 3: X-ray diffraction patterns of the ROM GB2, GB1 and JS samples and respective fraction $<44 \mu \mathrm{m}$. kao - kaolinite; msc muscovite; qtz - quartz; fdp - feldspar.

[Figura 3: Difratogramas de raios $X$ das amostras ROM GB2, GB1 e JS e respectiva fração $<44 \mu \mathrm{m}$. kao - caulinita; msc - muscovita; qtz - quartzo; fdp - feldspato.]

$<44 \mu \mathrm{m}$ of ROM GB2, GB1 and JS, indicating removal of the mineral impurities and higher concentrations of kaolinite after the granulometric classification in sieve of $44 \mu \mathrm{m}$. The Hinckler index of the fractions $<44 \mu \mathrm{m}$ of GB2, GB1 and JS were 1.16, 1.313 and 1.2, respectively. These values indicated that the kaolinite had high degree of structural order, which allowed inferring that the presence of iron (III) ions substituting the aluminum ions in the octahedral sites was not significant.

The chemical analysis of the fractions $<44 \mu \mathrm{m}$ of GB2, GB1 and JS showed levels of $\mathrm{SiO}_{2}$ and $\mathrm{Al}_{2} \mathrm{O}_{3}$ varying between 44.6 and $46.3 \%$ and 41.5 and $42.4 \%$, respectively. The loss on ignition was determined between 10.4 and $11.7 \%$ (Table II). These levels were proximate to the values established for theoretical kaolinite [11], indicating that after granulometric classification the kaolinite was enriched. The levels of $\mathrm{Fe}_{2} \mathrm{O}_{3}$ of the fractions $<44 \mu \mathrm{m}$ of GB2, GB1 and JS were less than $0.5 \%$, indicating small presence of iron oxides and hydroxides in the samples.

The scanning electron microscopy images indicate the fractions $<44 \mu \mathrm{m}$ of GB2, GB1 and JS were composed principally of well crystalized pseudohexagonal kaolinite disposed in the booklet morphology (Figs. 4A, 4B, 4D to $4 \mathrm{H}$ ) and, in low quantities, of mineralogical impurities dispersed in kaolin (Fig. 4C). The booklets of kaolinite showed average thickness between 5 and $10 \mu \mathrm{m}$, while the individual crystals showed average thickness around $1 \mu \mathrm{m}$ and average length between 2 and $20 \mu \mathrm{m}$.

The beneficiation with magnetic separation and chemical bleaching raised the brightness index (\%ISO), after magnetic separation, from 78.2 to $78.5 \%$ and from 91.3 to $92.5 \%$ in the fractions $<44 \mu \mathrm{m}$ of GB2 and GB1, respectively, while there was no alteration in $86.9 \%$ in the
Table II - Results of the chemical analysis by X-ray fluorescence of the fractions $<44 \mu \mathrm{m}$ of GB2, GB1 and JS. [Tabela II - Resultados das análises químicas por fluorescência de raios $X$ das frações $<44 \mu \mathrm{m}$ de GB2, GB1 e JS.]

\begin{tabular}{llll}
\hline Oxide & GB2 $(\%)$ & GB1 $(\%)$ & JS (\%) \\
\hline $\mathrm{SiO}_{2}$ & 46.30 & 45.10 & 44.60 \\
$\mathrm{Al}_{2} \mathrm{O}_{3}$ & 41.50 & 42.50 & 42.40 \\
$\mathrm{Fe}_{2} \mathrm{O}_{3}$ & 0.42 & 0.37 & 0.27 \\
Others & 1.31 & 0.51 & 1.22 \\
Loss on ignition & 10.40 & 11.70 & 11.30 \\
Sum & 99.93 & 100.18 & 99.79 \\
\hline
\end{tabular}

case of fraction $<44 \mu \mathrm{m}$ of JS. In the initial $30 \mathrm{~s}$ of chemical bleaching, increases from 78.5 to $90.9 \%, 92.5$ to $93.8 \%$, and 86.9 to $88.4 \%$ were observed in the fractions $<44 \mu \mathrm{m}$ of GB2, GB1 and JS, respectively. From 30 to $240 \mathrm{~min}$, the brightness index of the fractions $<44 \mu \mathrm{m}$ of GB2, GB1 and JS varied between 90.9 and $91.3 \%, 93.4$ and $93.8 \%$, and 88.5 and $89.0 \%$, respectively (Fig. 5a). The beneficiation with only chemical bleaching led to increases of brightness index (\% ISO) from 78.2 to $90.2 \%, 91.3$ to $95.7 \%$, and 86.9 to $90.4 \%$ in the fractions $<44 \mu \mathrm{m}$ of GB2, GB1 and JS in the first $30 \mathrm{~min}$ of chemical bleaching. From 30 to $240 \mathrm{~min}$, the brightness index of the fractions $<44 \mu \mathrm{m}$ of GB2, GB1 and JS varied between 90.2 and $93.5 \%, 94.3$ and $95.9 \%$, and 90.3 and $92.2 \%$, respectively (Fig. 5b).

The electron paramagnetic resonance spectra of the fractions $<44 \mu \mathrm{m}$ of GB2, GB1 and JS (Fig. 6) contained, in the region between 50 and $200 \mathrm{mT}$, resonance signals at 74 $\mathrm{mT}$ and in the triplet 135, 156 and $182 \mathrm{mT}$ [10], indicating that the iron (III) ions were distributed in the internal phase substituting the aluminum ions in the octahedral sites of the kaolinite structure. Nevertheless, this phase did not show any alteration during the beneficiation and its signals were less intense, corroborating the results of the Hinckler index, indicating that the presence of iron (III) ions was not significant. Resonances were also observed between 200 and $400 \mathrm{mT}$, representing iron (III) ions in the external phase, as iron oxides and hydroxides dispersed by kaolin [12]. The resonance signal at $350 \mathrm{mT}$ was identified and associated with radiation-induced defects (RID) [13]. This phase underwent alterations during the beneficiation.

In the beneficiation route with magnetic separation and chemical bleaching, after magnetic separation the area percentage between 200 and $400 \mathrm{mT}$ of the spectra of the fraction $<44 \mu \mathrm{m}$ of GB2 decreased from 62.15 to $46.29 \%$. The fractions $<44 \mu \mathrm{m}$ of GB1 and JS underwent slight variations, from 50.25 to $48.56 \%$, and 55.56 to $57.48 \%$. From magnetic separation to chemical bleaching during $30 \mathrm{~min}$ an increase was observed from 46.29 to $63.72 \%$ in the area percentage between 200 and $400 \mathrm{mT}$ of the spectrum of the GB2 sample, a slight increase from 48.56 to $53.26 \%$ in the case of fraction JS, and diminution from 

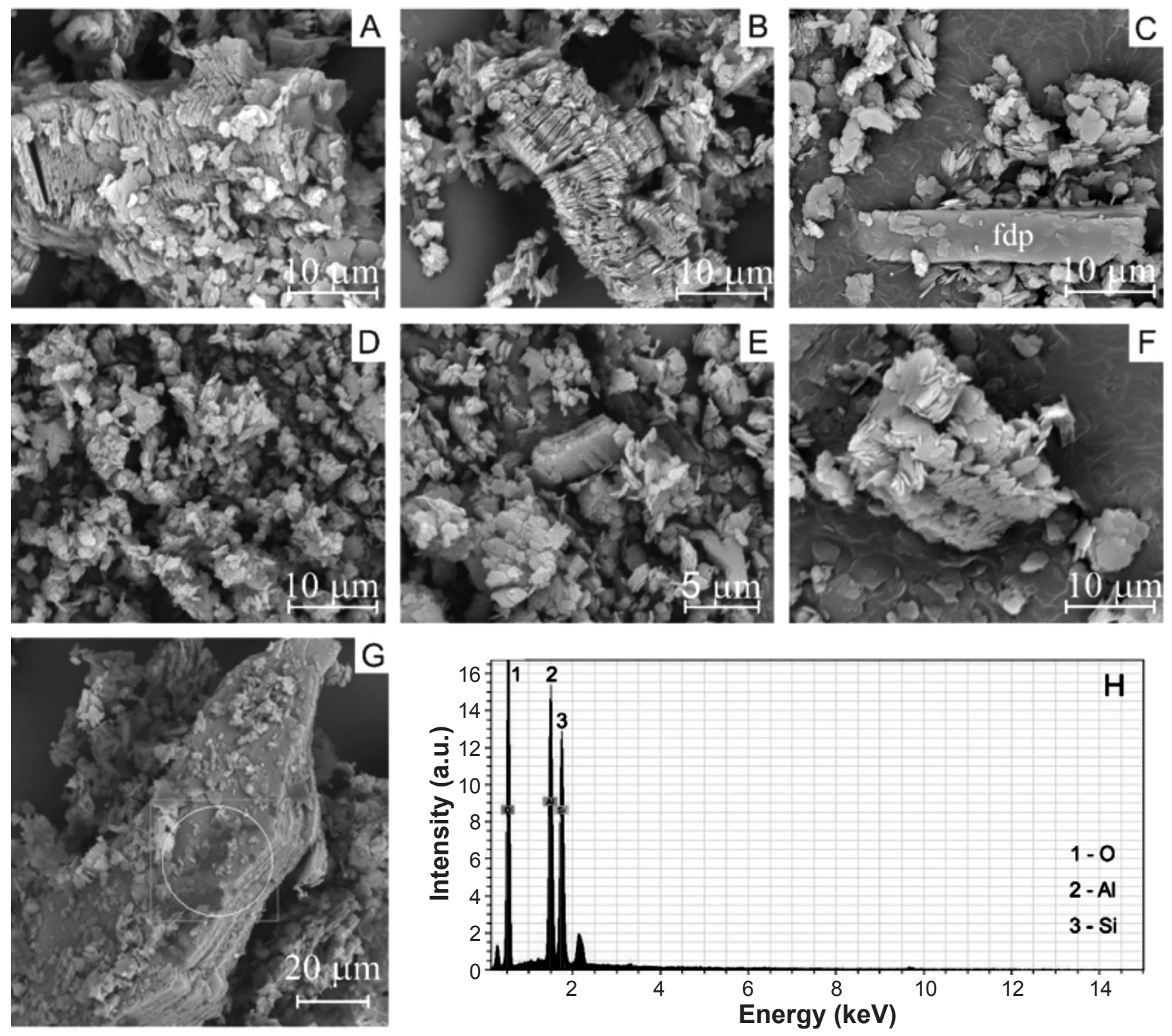

Figure 4: SEM images showing: A,B) kaolinite booklets of the fraction $<44 \mu \mathrm{m}$ GB2 with dimensions of $\sim 25 \mu \mathrm{m}$; C: feldspar (fdp) impurity with $\sim 20 \mu \mathrm{m}$ in the fraction $<44 \mu \mathrm{m}$ GB2; D,E,F) kaolinite booklets of the fraction $<44 \mu \mathrm{m}$ GB1 with thickness between 3 and $15 \mu \mathrm{m}$; G) kaolinite booklets of the fraction $<44 \mu \mathrm{m}$ JS with thickness of $\sim 20 \mu \mathrm{m}$ and length of $80 \mu \mathrm{m}$; and H) EDS spectrum indicating theoretical composition of kaolinite in the fraction $<44 \mu \mathrm{m}$ JS.

[Figura 4: Micrografias obtidas por microscopia eletrônica de varredura mostrando: A,B) booklets de caulinita da fração $<44$ m GB2 com dimensões de $25 \mu \mathrm{m} ; C$ ) impureza de feldspato (fdp) com $20 \mu \mathrm{m}$ na fração $<44 \mu \mathrm{m}$ GB2; D,E,F) booklets de caulinita da fração

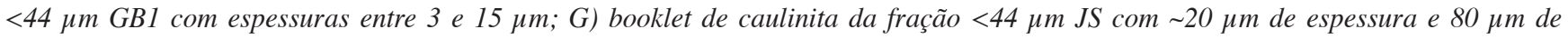
comprimento; e H) espectro de EDS indicando composição teórica de caulinita na fração <44 $\mu \mathrm{m}$ JS.]

57.48 to $43.52 \%$ regarding the fraction GB1. From 30 to $180 \mathrm{~min}$ of chemical bleaching, increases were observed from 63.72 to $64.30 \%$, and 53.26 to $53.31 \%$ in the area percentages between 200 and $400 \mathrm{mT}$ of the fractions GB2 and JS, respectively. In the case of the GB1 fractions, there was a decrease from 43.52 to $41.37 \%$ (Fig. 7a). In the beneficiation route without magnetic separation and with chemical bleaching, the area percentages between 200 and $400 \mathrm{mT}$, after $30 \mathrm{~min}$ of chemical bleaching, in the fraction $<44 \mu \mathrm{m}$ of GB2 increased from 62.15 to $72.79 \%$. The area percentages of the fractions of GB1 and JS underwent variations from 55.56 to $43.68 \%$, and 50.26 to $55.87 \%$, respectively. From 30 to $180 \mathrm{~min}$, variations were observed from 73.79 to $74.75 \%, 43.68$ to $47.38 \%$, and 55.87 to $56.13 \%$ in the area percentages of the fractions GB2, GB1 and JS, respectively (Fig. 7b). The increases of area percentages between 200 and 400 $\mathrm{mT}$ observed in the fraction GB2, after the first $30 \mathrm{~min}$ of chemical bleaching in the two beneficiation routes, occurred because the appearance of the sextet related to $\mathrm{Mn}^{2+}$ [12], increasing the area percentages of the regions of study of the spectra. The decreases of area percentage of the fraction GB1 agreed with the variations found in the evolution of the brightness index. The area percentage 

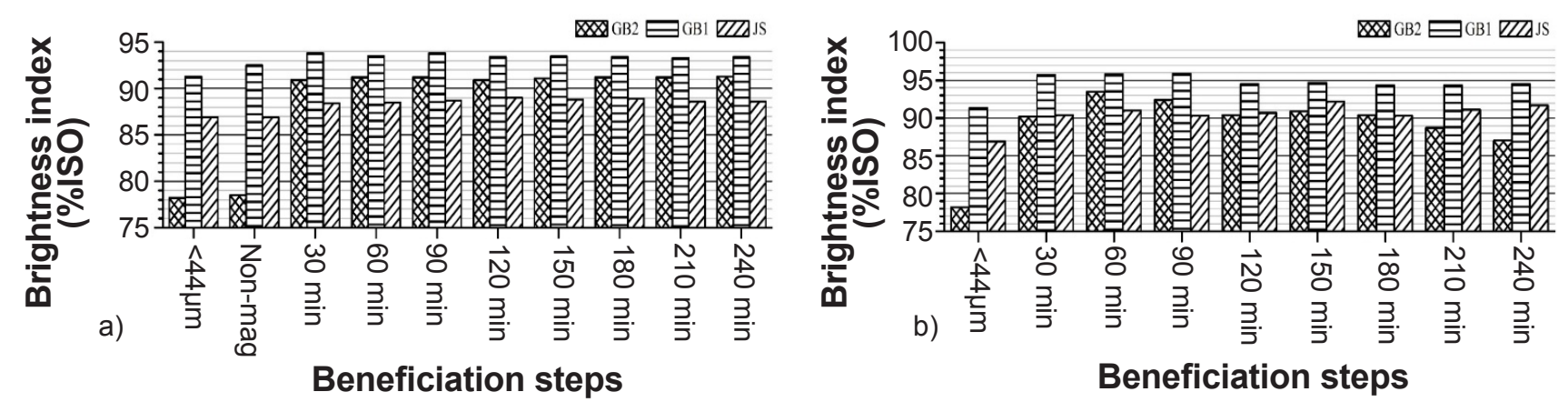

Figure 5: Variation of brightness index of the fractions $<44 \mu \mathrm{m}$ of GB2, GB1 and JS: (a) after magnetic separation and during chemical bleaching in the first beneficiation route; (b) during chemical bleaching in the second beneficiation route.

[Figura 5: Variação do índice de alvura das frações $<44$ um de GB2, GB1 e JS: (a) após a separação magnética e durante o alvejamento químico na primeira rota de beneficiamento; $(b)$ durante o alvejamento químico na segunda rota de beneficiamento.]
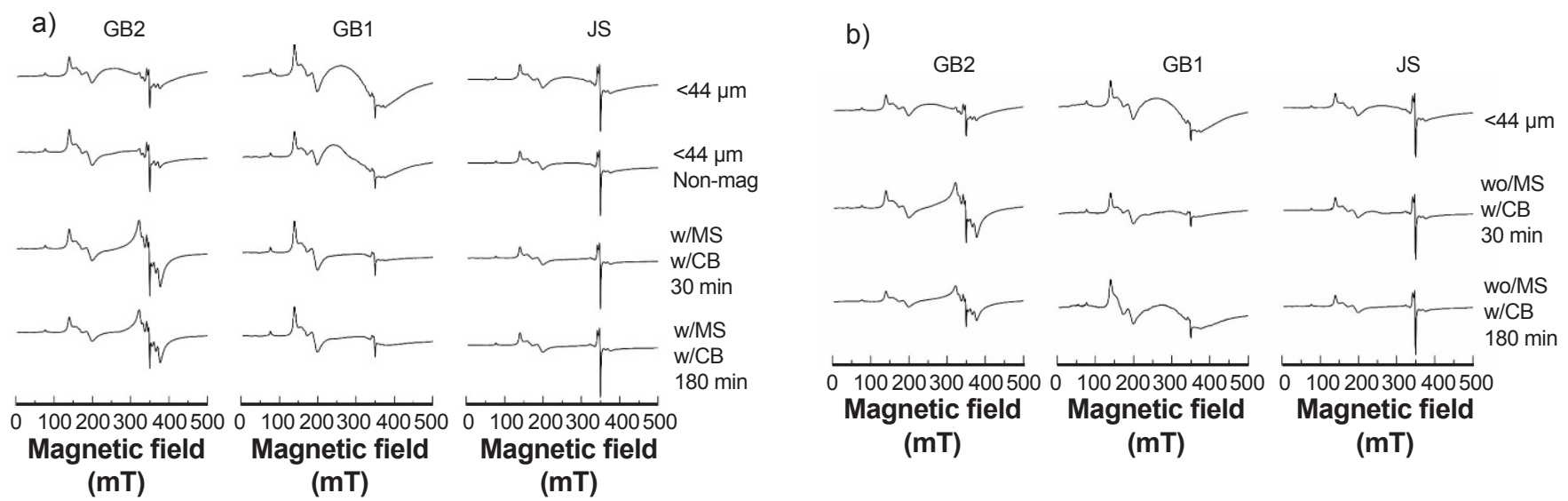

Figure 6: Electron paramagnetic resonance spectra of the fractions <44 $\mu \mathrm{m}$ of GB2, GB1 and JS of the beneficiation route: (a) with magnetic separation and chemical bleaching; (b) without magnetic separation and with chemical bleaching. w/MS - with magnetic separation; w/CB - with chemical bleaching; wo/MS - without magnetic separation.

[Figura 6: Espectros de ressonância paramagnética eletrônica das frações <44 um de GB2, GB1 e JS da rota de beneficiamento: (a) com separação magnética e alvejamento químico; (b) sem separação magnética e com alvejamento químico. w/MS - com separação magnética; w/CB - com alvejamento químico; wo/MS - sem separação magnética.]
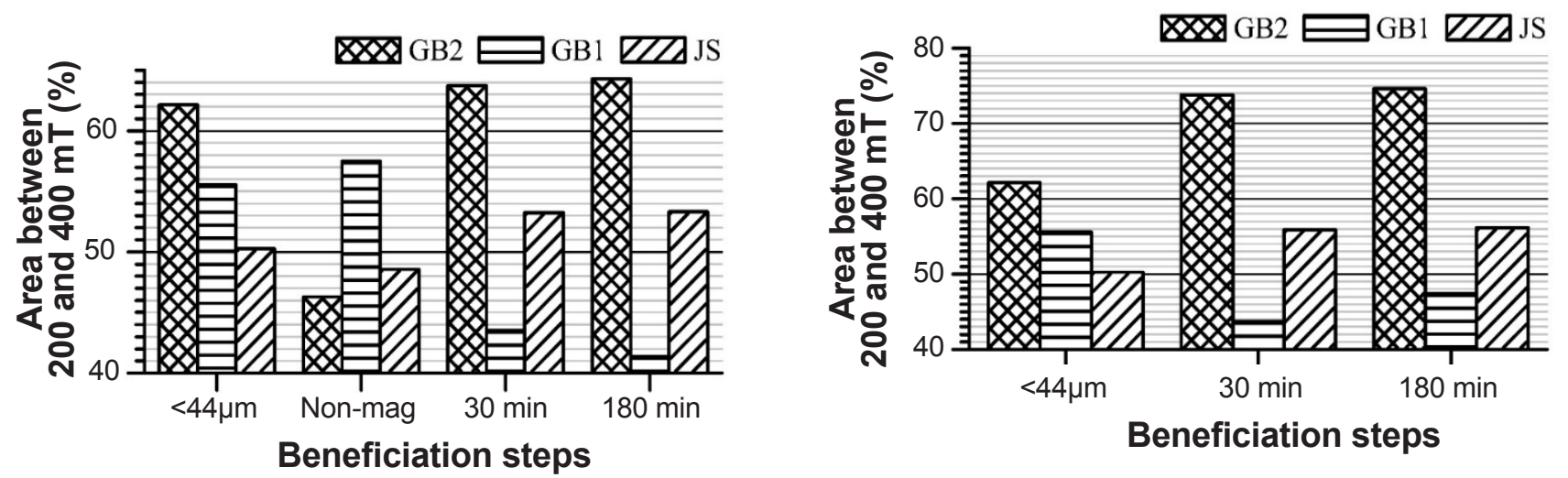

Figure 7: Variations of area percentages between 200 and $400 \mathrm{mT}$ of the spectra of the fractions <44 $\mu \mathrm{m}$ of GB2, GB1 and JS during the beneficiation with: (a) magnetic separation and chemical bleaching; (b) only chemical bleaching.

[Figura 7: Variações das porcentagens de área entre 200 e $400 \mathrm{mT}$ dos espectros das frações <44 $\mu \mathrm{m}$ de GB2, GB1 e JS durante o beneficiamento com: (a) separação magnética e alvejamento químico; (b) somente alvejamento químico.]

increase of the fraction GB1, verified between 30 and $180 \mathrm{~min}$ of chemical bleaching, can be due to the reprecipitation of iron oxides and hydroxides after 120 min of treatment [14]. The variations related to the fraction JS were unrepresentative because the signals between 200 and 400 mT had low intensities (Figs. 6 and 7). 


\section{CONCLUSIONS}

The results showed that the fractions $<44 \mu \mathrm{m}$ of kaolin samples (GB1 and GB2 from Equador, Rio Grande do Norte - RN, and JS, from Junco do Seridó, Paraíba - PB) were composed mainly by well-crystalized pseudohexagonal kaolinite in booklet morphology, and secondarily by muscovite, quartz and feldspar dispersed through the kaolin. The iron (III) ions were distributed in the internal phase, substituting the aluminum ions in the octahedral sites in the kaolinite structure, and in the external phase, as iron oxides and hydroxides. Electron paramagnetic resonance was a suitable technique to analyze the variation of iron oxides and hydroxides during beneficiation of kaolin. The separation in a magnetic induction of 14000 gauss and chemical bleaching with sodium dithionite were able to remove iron oxides and hydroxides, which resulted in increase of the brightness index in the fractions $<44 \mu \mathrm{m}$ of GB1, GB2 and JS. Magnetic separation was less effective in removing iron oxides and hydroxides, resulting in small increases of the brightness index. Chemical bleaching alone for just 30 min was sufficient to remove most of the iron oxides and hydroxides, which generated biggest increases of the brightness index. The chemical bleaching when done for more than $30 \mathrm{~min}$ did not promote significant increases of the brightness index, which indicates no need for this treatment with duration longer than this period. The beneficiation of the fractions $<44 \mu \mathrm{m}$ of GB1, GB2 and JS without magnetic separation resulted in removals of iron oxides and hydroxides and increases of brightness index similar to the beneficiation with magnetic separation, indicating that this process may not be necessary in beneficiation plants of the kaolin from Equador (RN) and Junco do Seridó (PB), which can enable reductions of costs promoting better exploitation of the ore of the Brazilian Northeast region. The kaolin of samples GB1, GB2 and JS, after beneficiation, showed suitable characteristics for use in paper industries, as filler and coating, and in ceramic industries.

\section{ACKNOWLEDGEMENTS}

We thank Centro de Tecnologia Mineral (CETEM) and Conselho Nacional de Desenvolvimento Científico e
Tecnológico $(\mathrm{CNPq})$ for financial support, Centro Brasileiro de Pesquisas Físicas (CBPF), Fundação de Amparo à Pesquisa do Estado do Rio de Janeiro (FAPERJ), Setor de Caracterização Tecnológica of the Coordenação de Análises Minerais for technical support. This study is part of the Projeto Entidades Associadas of the CETEM.

\section{REFERENCES}

[1] S.M. Petterson, H.H. Murray, in Clays, $4^{\text {th }}$ Ed., S.J. Lefond (Ed.), Am. Inst. Min. Metal. Petrol. Eng. (1975) 519-585.

[2] M.S. Prasad, K.J. Reid, H.H. Murray, Appl. Clay Sci. 6 (1991) 87.

[3] E.P. Scorza, "Província Pegmatítica da Borborema", DNPM-DGM Rio de Janeiro, Boletim 112 (1944).

[4] E.A. Madeiros Lima, A.A. Wanderley, A.T. Vieira, A.I.M. Medina, A.J. Barbosa, A.M. Vasconcelos, C.A. Amaral, E.Y. Sato, E.H.R. O. Silva, J.F. Leite, J.F.S. Moraes, J.A. Ribeiro, J.R. Nesi, L.A.A. Angelim, M.E.V. Calheiros. "Projeto scheelita do Seridó - relatório final", DNPM/CPRM, Recife (1980).

[5] F.A.N.G. Silva, A.B. Luz, J.A. Sampaio, L.C. Bertolino, R.B. Scorzelli, M. Duttine, F.T. da Silva, Appl. Clay Sci. 44 (2009) 189.

[6] A.B. Luz, A.R. Campos, E.A. Carvalho, L.C. Bertolino, R.B. Scorzelli, Rochas e minerais industriais, $2^{\text {a }}$ Ed., Cent. Tecnol. Miner., Rio de Janeiro (2008) 255.

[7] H.H. Murray, Int. J. Miner. Beneficiation 7 (1980) 263.

[8] A.H. Ichihara, Sumário Mineral (2015) 42.

[9] D.N. Hinckley, Clays Clay Miner., in $11^{\text {th }}$ Nat. Conf. Clays Clay Miner., A. Swineford, P. C. Franks (Eds.), Pergamon Press, New York (1963) 229-235.

[10] R.E. Meads, P.J. Malden, Clay Miner. 10 (1975) 313.

[11] H.H. Murray, W.D. Keller, Kaolin: genesis and utilization, $1^{\text {st }}$ Ed., The Clay Miner. Soc., Boulder (1993) 1.

[12] R.B. Scorzelli, L.C. Bertolino, A.B. Luz, M. Duttine, F.A.N.G. Silva, P. Munayco, Clay Miner. 43 (2008) 129.

[13] B. Clozel, T. Allard, J.P. Muller, Clays Clay Miner. 42 (1994) 657.

[14] L.C. Bertolino, A.M. Rossi, R.B. Scorzelli, M.L. Torem, Appl. Clay Sci. 49 (2010) 170.

(Rec. 04/10/2016, Rev. 23/10/2016, 24/12/2016, Ac. 24/12/2016) 